\title{
A new species of Anchoviella Fowler, 1911 (Clupeiformes: Engraulidae) from the mouth of the São Francisco River, Brazil
}

\author{
Uma nova espécie de Anchoviella Fowler, 1911 (Clupeiformes: Engraulidae) da foz do rio São \\ Francisco, Brasil
}

José Milton Barbosa*, Aline Gabrielle Gomes da Silva, Ana Rosa da Rocha Araújo \& Marina Feitosa Carvalho

Federal University of Sergipe - UFS

*E-mail: jmiltonb11@gmail.com

Received: November 19, 2015 (resubmitted on May 17, 2017); Accepted: August 1, 2017 / Published: December 26, 2017

\begin{abstract}
Anchoviella sanfranciscana, sp. n. is described for the estuary of the São Francisco River (States of Sergipe and Alagoas, northeastern Brazil). It is distinguished from its congeners by a combination of the following characteristics: (1) a very wide silver lateral band with above another well-defined dark brown and yellow lateral band - its total width is 1.5 to 2 times wider than the ocular diameter; (2) the distance from the tip of the dorsal fin to the start of the anal fin is similar in size as the dorsal fin itself; and (3) the number of rakers in the lower branch of the first branchial arch is unique among its congeners, 29-35, and in this respect it is comparable only to $A$. cayennensis. However, A. sanfranciscana has a more robust body than A. cayennensis and is anatomically similar to that of A. lepisdostostole, from which it is distinguished by the position of the insertion of the anal fin in relation to the dorsal fin.
\end{abstract}

Keywords: Brazil, fishes, systematics, anchovies.
Resumo Anchoviella sanfranciscana, sp. n. é descrita para o estuário do rio São Francisco (estados de Sergipe e Alagoas, nordeste do Brasil). Distingue-se de outras espécies do gênero Anchoviella por uma combinação das seguintes características: (1) a uma banda lateral prateada muito larga, e bem definida que é marrom escuro e amarelo na parte superior, a largura é de 1,5 a 2 vezes maior do que o diâmetro ocular (2), a distância da ponta da nadadeira peitoral para a origem da nadadeira anal é semelhante ao tamanho da primeira e (3) número de rastros no ramo inferior do primeiro arco branquial é único entre os seus congêneres, 29-35, e a este respeito, é semelhante apenas a A. cayennensis. No entanto, A. sanfranciscana tem um corpo mais robusto do que A. cayennensis é anatomicamente semelhante a A. lepisdostostole, da qual se distingue pela posição de inserção da nadadeira anal em relação à dorsal.

Palavras-chave: Brasil, peixes, sistemática, manjubas. 


\section{Introduction}

Anchoviella is one of the most species-rich genera of the Engraulidae, with about 17 valid marine, estuarine, and freshwater species distributed in South American rivers and along the North and Central part of the Atlantic and Pacific coasts (Whitehead, Nelson \& Wongratana, 1988; Nelson, Grande \& Wilson, 2016). Engraulidae, which includes approximately 140 species, are typically schooling coastal fishes commonly known as anchovies, "manjubas" in the Brazilian Portuguese (Di Dario, 2009; Nelson, 2016) or "pilombeta" from São Francisco Basin (Barbosa et al. 2017).

According to Loeb (2012). Anchoviella is composed of small fish (with a standard length varying between 3-14 cm) from the marine, estuarine, or freshwater habitats distributed throughout South, Central, and North America the genus is part of the Engraulidae by a slightly compressed body, the presence of usually more than 15 elongate gill rakers on the lower branch of the first gill arch, and a short upper jaw not extending beyond the vertical through the anterior margin of the operculum. (Whitehead, Nelson \& Wongratana, 1988).

Loeb \& Figueiredo (2014) reported from the lower portion of the São Francisco basin that Anchoviella lepidentostole has been recorded from the mouth of the São Francisco River, Anchoviella cf. cayennensis (Puyo, 1946) from Piaçabuçu, both species found up to Penedo (Alagoas State), and A. brevirostris only reported at Piaçabuçu (Alagoas State). The recordings of $A$. vaillanti were all restricted to the upper parts of the river.

The taxonomic history of the genus Anchoviella Fowler, 1911 reveals a complexity that is not yet fully understood. Morphological traits such as body shape and meristic counts have been widely used for fish identification. The objective of the present paper is to give a formal description of A. sanfranciscana, it`s morphometric and meristic traits and to relate this species with other species of the genus Anchoviella.

\section{Material and Methods}

The holotype and 19 paratypes of "pilombeta-pau” (i.e. its local name) were collected near the estuary of São Francisco River, between Brejo Grande (Sergipe State) and Piaçabuçu (Alagoas State) (Figure 1).

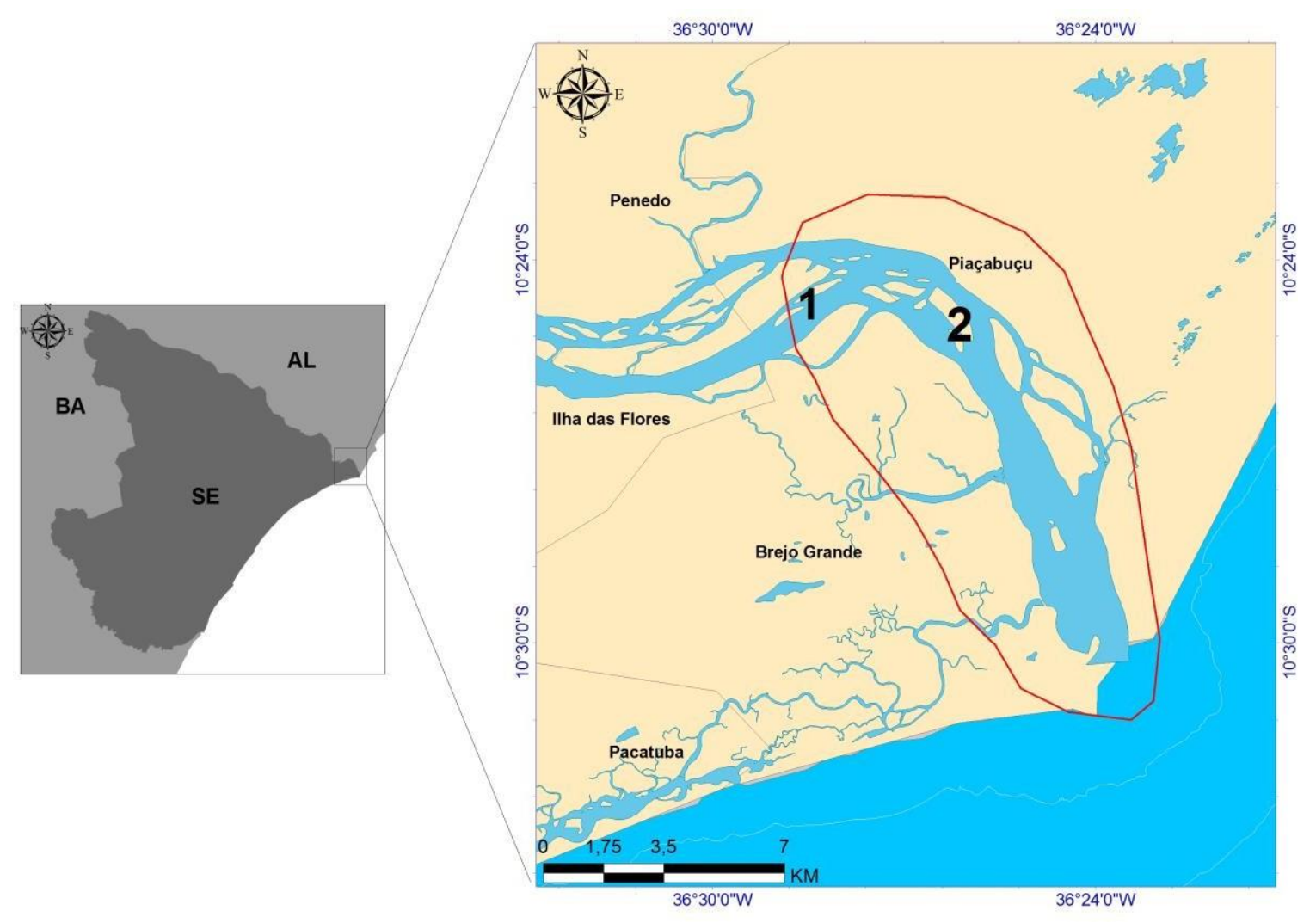

Figure 1. Area of occurrences in São Francisco River estuary: (1) the vicinity of Brejo Grande town and (2) Saramen village in Brejo Grande municipality. 
Acta of Fisheries and Aquatic Resources

The specimens were fixed in formalin, later transferred into $75 \%$ ethanol, and ultimately deposited in the National Institute for Amazonian Research (INPA).

The techniques for taking measurements of the morphometric characteristics and the meristic data counts were performed on specimens (including the holotype and the paratypes) according to Hildebrand (1963), Whitehead (1985), Whitehead, Nelson \& Wongratana (1988), with the modifications described by Loeb (2012). Morphometric measurements were taken from the left side of the sample, and measured to the nearest $0.01 \mathrm{~cm}$ using a digital caliper. The standard length (SL) is expressed in $\mathrm{mm}$ and other measures are expressed as a percentage of SL or head length (HL). The vertebrae count, presented in table 1, is based on two specimens prepared according to Taylor \& van Dyke (1985).

\section{Results}

\section{Anchoviella sanfranciscana, new species (Figures 2-5; Tables 1-2)}

Holotype. INPA-ICT 053278, 106.0 mm SL, northeastern Brazil, São Francisco River estuary between the cities of Brejo Grande, State of Sergipe, and Piaçabuçu, State of Alagoas (UTM - Universal Transverse Mercator Coordinate System: 10.412240 S, 36.457890 W). A.G.S. Silva \& A.R.R. Araújo, April 12, 2015.

Paratypes. INPA-ICT 053279, 19 samples, São Francisco River estuary between the cities of Brejo Grande, State of Sergipe, and Piaçabuçu, State of Alagoas (10.412240 S; 36.457890 W). April 12, 2016. INPA-ICT 053280, 15 samples (103.6-128.0 mm SL). São Francisco River estuary near of Saramen Village in the municipality of Brejo Grande, State of Sergipe (10.472844 S; 36.417388 W). A.G.S. Silva \& A.R.R. Araújo, November 19, 2015 (Participatory Monitoring of Fishing Landing Project).



Figure 2. Anchoviella sanfranciscana, new species, holotype INPA-ICT 053278, approx. $106.0 \mathrm{~mm}$ SL, preserved in alcohol, from Brejo Grande, estuary of São Francisco River, State of Sergipe.

Diagnosis. Anchoviella sanfranciscana can be distinguished from its congeners by the following characteristics: (1) the presence of wide silver lateral band, with a well-defined dark brown and yellow lateral band above - it's total width is 1.5 to 2 times wider than the ocular diameter, while in other species the width is less than 1 time; (2) the distance from tip of dorsal fin to start of anal fin is similar in size as the dorsal fin, while in other species the distance is smaller, with the exception of A. perfasciata; and (3) the number of gill rakers in lower branch of the first branchial arch is 29-35, while in other species the maximum is 27 , except for $A$. cayennensis.

Description. Morphometric data of 20 specimens, including the holotype and the paratypes presented in Table 1. Small size fishes, with a total length not exceeding $160 \mathrm{~mm}$ and with a standard length of $130 \mathrm{~mm}$. The body is elongate and strongly compressed. The subterminal mouth is sloping in relation to the axis of the body, with small, sharp teeth, which are curved to the inside of the mouth and are arranged in a single row. It shows a pair of nasal orifices. There are small pseudo-gills that do not reach the operculum, with size ranging from 3.3-5.3 mm; the posterior margin of the maxilla does not reach the posterior margin of the preoperculum. These last two characteristics are common to the species of the genus Anchoviella.

It displays a strong convex ventral profile in the anterior part and a soft region in the posterior part to the base of the caudal fin. The base of the anal fin is located posterior to the last ray of the dorsal fin. The dorsal fin has a slightly convex distal margin. It has a longitudinal band along the body, of silver coloration, very wide, starting at the posterior margin of the head to the caudal peduncle, with greater width in the vertical that passes in the beginning of the base of the anal fin - its width is at least 1.5 greater than the diameter of the orbit. It shows melanophores and a narrow strip with coloration that ranges from dark brown to yellow, more pronounced in the anterior region (Figures 2-3). 
Table 1. Morphometric and meristic characteristics of Anchoviella sanfranciscana: 20 specimens, including holotype and 19 paratypes, $\mathrm{SD}=$ Standard Deviation (frequency in parenthesis).

\begin{tabular}{|c|c|c|c|}
\hline \multirow{2}{*}{ Measurements (mm) } & \multirow[t]{2}{*}{ Holotype } & \multicolumn{2}{|c|}{ Range } \\
\hline & & Min & $\operatorname{Max}$ \\
\hline Standard length (SL) & 106.0 & 103.6 & 128.0 \\
\hline Head length (HL) & 23.0 & 22.6 & 27.5 \\
\hline Orbital diameter & 6.0 & 5.7 & 7.5 \\
\hline Silvery lateral band & 9.9 & 8.6 & 11.4 \\
\hline \multicolumn{4}{|c|}{ Orbital Diameter in Silvery Lateral Band } \\
\hline Orbital diameter & 1.7 & 1.5 & 2.0 \\
\hline \multicolumn{4}{|c|}{ Percentages of Standard Length } \\
\hline Head length & 21.0 & 19.8 & 23.4 \\
\hline Body depth & 22.1 & 19.2 & 26.4 \\
\hline Caudal peduncle depth & 9.0 & 8.0 & 10.3 \\
\hline Dorsal-fin base length & 12.1 & 11.3 & 15.6 \\
\hline Anal-fin base length & 13.1 & 11.1 & 15.8 \\
\hline Pelvic fin length & 12.3 & 10.2 & 15.6 \\
\hline Pectoral fin length & 15.1 & 12.0 & 17.2 \\
\hline Predorsal length & 54.2 & 53.3 & 68.2 \\
\hline Preanal length & 71.2 & 67.8 & 87.7 \\
\hline Prepelvic length & 46.4 & 40.7 & 58.1 \\
\hline Prepectoral length & 24.1 & 21.6 & 29.1 \\
\hline \multicolumn{4}{|c|}{ Percentages of Head Length } \\
\hline Snout length & 21.2 & 17.7 & 22.9 \\
\hline Orbital diameter & 27.4 & 24.7 & 29.2 \\
\hline Upper Jaw length & 63.0 & 62.5 & 67.2 \\
\hline Lower Jaw length & 63.9 & 63.0 & 67.2 \\
\hline Interorbital width & 21.7 & 19.8 & 32.1 \\
\hline Counts & \multicolumn{3}{|c|}{ Range (frequency in parenthesis) } \\
\hline Total dorsal-fin rays & \multicolumn{3}{|c|}{$13(3), 14(13), 15(14)$} \\
\hline Total anal-fin rays & \multicolumn{3}{|c|}{$13(4), 14(8), 15(16), 16(3)$} \\
\hline Total pectoral-fin rays & \multicolumn{3}{|c|}{$14(11), 15(19)$} \\
\hline Total pelvic-fin rays & \multicolumn{3}{|c|}{$7(30)$} \\
\hline \multirow[t]{2}{*}{ Vertebrae } & \multicolumn{3}{|c|}{$42(2)$} \\
\hline & \multicolumn{3}{|c|}{ Gill Rakers on $1^{\text {st }}$ Gill Arch } \\
\hline Upper branch & \multicolumn{3}{|c|}{$19(3), 20(2), 21(6), 22(14), 23(3), 24(2)$} \\
\hline Lower branch & \multicolumn{3}{|c|}{$29(10), 3(4), 31(3), 32(4), 33(7), 34(1), 35(1)$} \\
\hline Total & \multicolumn{3}{|c|}{$48(2), 49(3), 50(2), 51(4), 52(2), 53(4), 54(3) 55(8), 56(1), 57(1)$} \\
\hline
\end{tabular}

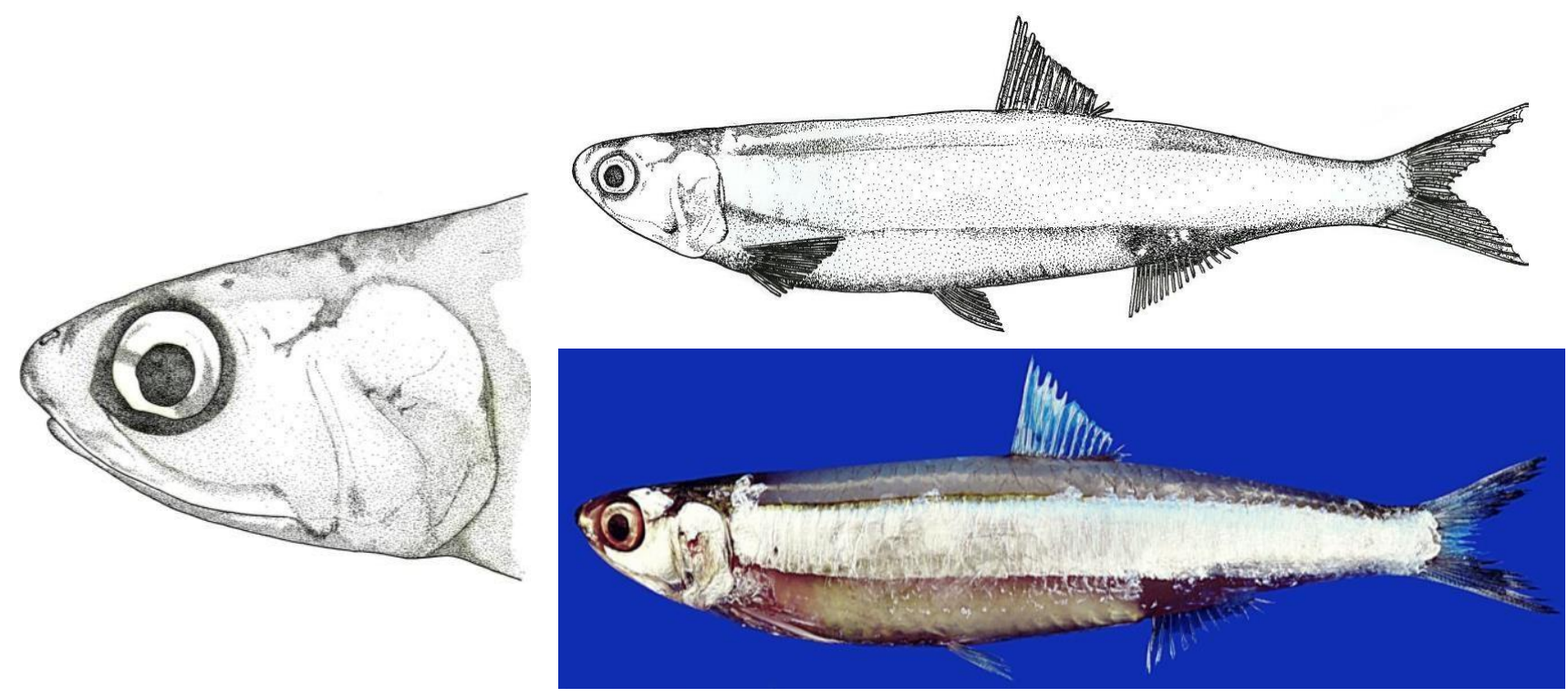

Figure 3. Anchoviella sanfranciscana new species, topotype, approx. 120.0 mm SL from São Francisco River estuary (drawings by Diego Godinho and photography by Matheus Deda). 
Acta of Fisheries and Aquatic Resources

Coloration alive. The species shows an overall whitish color, with a very wide silver sideband and a welldefined dark brown and yellow side band on top of the silver lateral band - this coloration of the whole lateral band disappears when the fish is preserved in alcohol. All the fins are translucent; the caudal fin shows a black border, and is light white and translucent in some parts.

Coloration in alcohol. Body color is overall milky white, with a silver longitudinal band and melanophores in its superior margin from the back of the operculum to the caudal peduncle. Melanophores are present on head, snout, and along all dorsal outlines, which are arranged in two rows, with a black spot at the start of the dorsal fin base. There is an orbit silver staining, also in the part after the orbit near to the posterior margin of the operculum.

Etymology. The name of the species sanfranciscana is a noun in the genitive case that refers to the place of occurrence of the species, at the São Francisco River.

Distribution. The estuary of the São Francisco River in the region of Cabeço: (1) close to the sea in the municipality of Brejo Grande, State of Sergipe; and (2) upstream near to the city of Penedo, State of Alagoas. Currently, with the reduction of the water discharge due to the São Francisco dams and the consequent increase of salinity at its mouth, Anchoviella have also been found in regions upstream of the São Francisco River.

Remarks. Anchoviella sanfranciscana presents external anatomy similar to the A. lepidentostole and is sympatric with A. lepidentostole in the estuary of São Francisco River, even forming mixed shoals. However, they differ mainly by the position of the anal fin relative to the base of the dorsal fin. Compared to the other species the principal difference is the number of traces in the first branchial arch. Where the $A$. sanfranciscana has 29 to 35 traces, whereas the others have less than 30 traces, with the exception of $A$. cayennensis, which also has 29 to 35 traces in the first branchial arch. However, there are marked differences between the two species, to wit: (1) the silver lateral band is very wide, 1.5 to 2 times wider than the diameter of the eye, whereas in the A. cayennesis it is narrower; and (2) the distance from the tip of the pectoral fin to the start of the ventral fin is longer, similar to the pectoral fin size; in the A. cayennensis this distance is less than half the length of the pectoral fin. The A. sanfranciscana is a species confined to brackish water and live in areas close to the river mouth, dependent on the salinity of the water - when the salinity is high the fish migrate into the river. This effect is a result of the declining flow due to hydroelectric dams upsteam.

\section{Identification of Anchoviella sanfranciscana}

According to Whitehead, Nelson \& Wongratana (1988) the genus Anchoviella is composed by the 15 species: seven inhabit fresh water, two occur in the Pacific Ocean, and six happens in the Atlantic Ocean. Loeb (2012) describes another freshwater specie A. juruasanga. According to Cervigón et al. (1992) A. guianensis occurs in the Atlantic, inhabiting river estuaries in North America region. Thus, seven species can serve as a comparison case for A. sanfranciscana sp. $\mathrm{n}$.

According to the position of the start of the anal fin in relation to the base of the dorsal fin the species of the genus Anchoviella show two patterns (Figure 4).

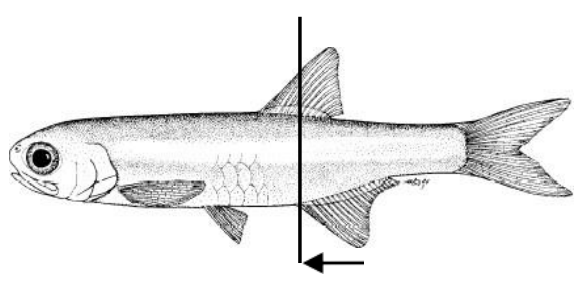

Pattern 1

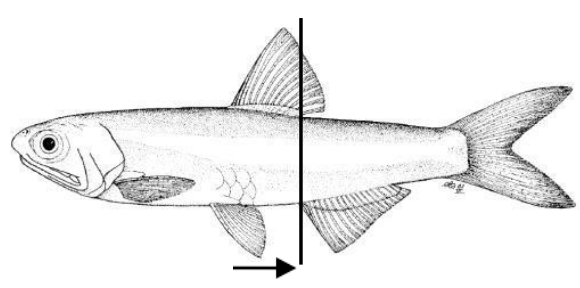

Pattern 2

Figure 4. Anal fin position in relation to the dorsal fin in Anchoviella. Pattern 1: the vertical that cuts the origin of the anal fin passes near to the center of the dorsal fin base or more anteriorly; and pattern 2: the vertical that cuts the origin of the anal fin passes near to the last ray of the dorsal fin or more posteriorly. 
Among the species found in the Atlantic Ocean four display pattern 2 (A. brevirostris, A. cayennensis, A. guianensis, and $A$. perfasciata), analogue to the A. franciscana $\mathrm{sp}$. $\mathrm{n}$. The main characteristics that differentiate these species are presented in Table 2.

Table 2. Characteristics that distinguish Anchoviella sanfranciscana sp. $\mathrm{n}$. from similar species occurring in the Atlantic Ocean.

\begin{tabular}{|c|c|c|c|c|c|c|}
\hline Species & $\mathrm{SL}(\mathrm{mm})^{1}$ & $\mathrm{SnL} \mathrm{OD}^{2}$ & BLat/OD 3 & RtI $1^{\circ}-$ ramo $^{4}$ & $\mathrm{SL} / \mathrm{BD}^{5}$ & $\mathrm{RAn}^{6}$ \\
\hline A. sanfranciscana sp. $\mathrm{n}$. & 13 & $>1 / 2$ & $1,5-2$ & $29-35$ & $4.85-5.15$ & $13-16$ \\
\hline A. brevirostris* & 9 & $1 / 2$ & $3 / 4$ & $\overline{23-27}$ & $4-5$ & $15-17$ \\
\hline A. cayenensis* & 12 & $1 / 2$ & $3 / 4$ & $29-35$ & 5.5 & $15-17$ \\
\hline A. guianensis* & 9 & $1 / 2$ & $1 / 2$ & $\overline{20-26}$ & $4-5$ & $17-21$ \\
\hline A. perfaciata* & 11 & $3 / 4$ & $3 / 4-1$ & $24-30$ & 5.5 & $13-18$ \\
\hline
\end{tabular}

${ }^{1}$ Standard length; ${ }^{2}$ Snout Length / Orbital Diameter; ${ }^{3}$ Silvery Lateral Band / Orbital Diameter; ${ }^{4}$ Gill Rakers on $1{ }^{\text {st }}$ Gill Arch, Lower branch; ${ }^{5}$ Standard Length / Body Depth; ${ }^{6}$ Total Anal Fin Rays

*Data based on Whitehead (1985), Whitehead, Nelson \& Wongratana (1988) and Cervigón et al. (1992).

The nearest species to A. franciscana sp. $\mathrm{n}$. with respect to the above mentioned morphometric aspects is A. cayennenis. However, the radiograph shows the difference between the two species (Figure 5).

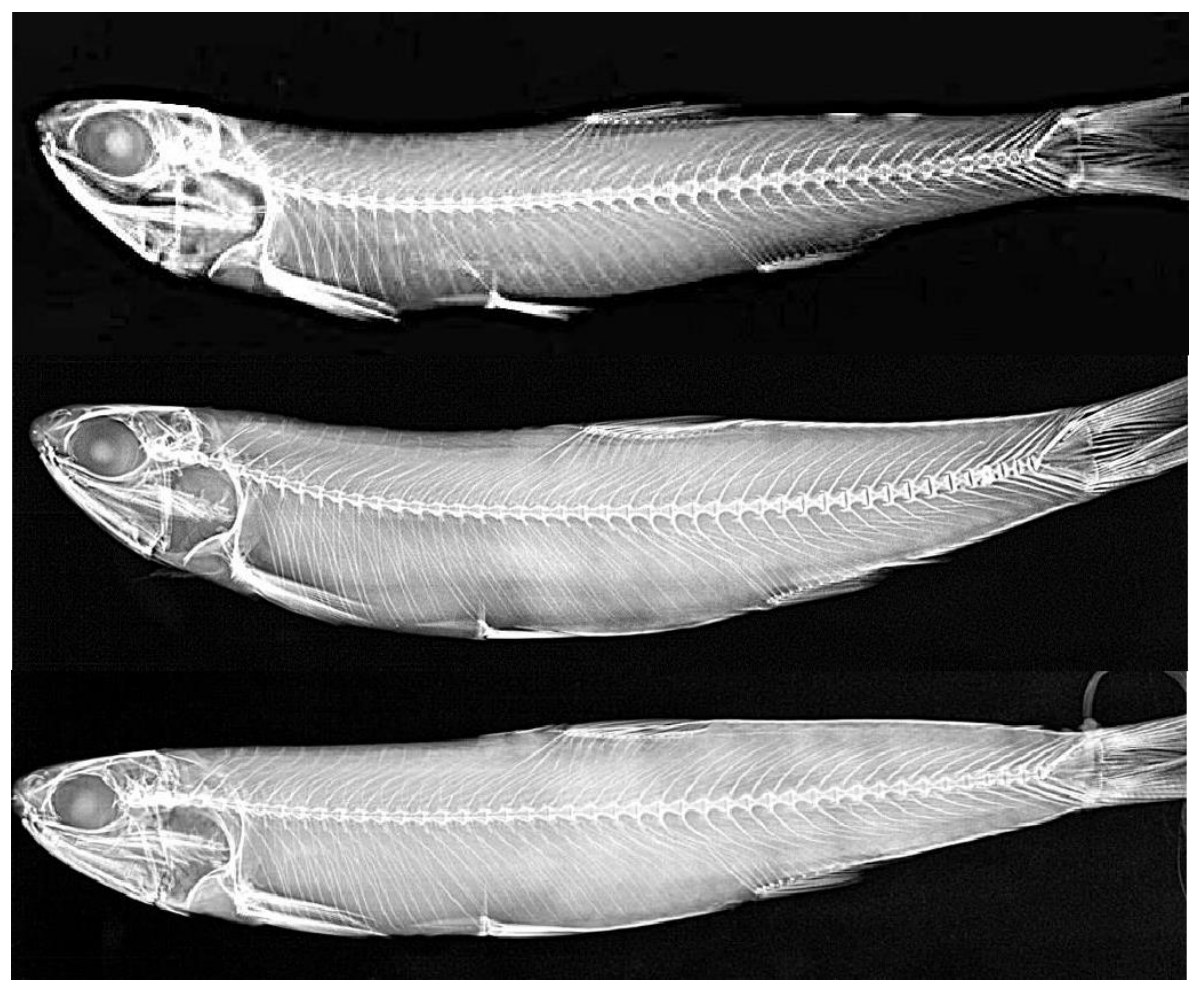

Figure 5. The radiographies of (1) A. cayennensis (credit: Sandra Raredon, NMHN) and A. sanfranciacana (2) INPAICT053280 Paratype and (3) INPA-ICT053278 Holotype (credit Lucia Rapp Py-Daniel, INPA).

\section{Acknowledgements}

To the researchers from the National Institute for Amazonian Research (INPA) Dra. Lucia Rapp PyDaniel, curator of the fish collection, and Dr. Efrem Jorge Ferreira for the cataloging the types in the INPA collection, also to the researchers Diego Godinho and Dr. Diego Zacardi of the Federal University of the Western Pará, for making fish drawings viable, to Fishing Engineer Matheus Deda for the photography of the species, to Dr. Raniere Garcez of the Federal University of Rondônia for the correction of the manuscript and Dra. Lucia Goes Federal University of Sergipe for the suggestions. 


\section{References}

Barbosa, J.M., Soares, E.C., Cintra, I.H.A., Hermann, M. \& Araújo, A.R.R. (2017). Perfil da ictiofauna do rio São Francisco. ActaFish 5(1): 70-90.

Cervigón, F., Ciaprini, R., Fisher, W., Garibaldi, L. Hendrickx, M. Lemus, A.J., ... Rodriquez, B. (1992). Guía de campo de las especies comerciales marinas e salobres de la costa septentrional de Sur América. Roma: FAO.

Di Dario, F. (2009). Chirocentrids as engrauloids: evidence from suspensorium, branchial arches, and infraorbital bones (Teleostei, Clupeomorpha). Zool. J. Linnean. Soc., 156: 363-383.

FAO (2016). The State of World Fisheries and Aquaculture. Roma: FAO.

Fowler, H. W. (1911). Notes on clupeoid fishes. Proc. Acad.Nat. Sci. Philadelphia, 63: 204-221.

Hildebrand, S. F. (1963). A review of the American anchovies (family Engraulidae). Bull, Bingham Ocean. Coll. Yale University, 8: 1-165.

Loeb, M.V. (2012). A new species of Anchoviella Fowler, 1911 (Clupeiformes: Engraulidae) from the Amazon basin, Brazil. Neotropical Ichthyology, 10(1): 13-18

Loeb, M.V. \& Figueiredo, J.L. (2014) Redescription of the freshwater anchovy Anchoviella vaillanti (Steindachner, 1908) (Clupeiformes: Engraulidae) with notes on the distribution of estuarine congeners in the Rio São Francisco basin, Brazil. Arquivos de Zoologia, 45 (esp.): 33-40

Nelson, J.S. Grande \& Wilson, (2016). Fish of the world, 5th Ed. New Jersey: John Wiley \& Sons.

Taylor, W.R. \& G.C. van Dyke. (1985). Revised procedures for staining and clearing small fishes and other vertebrates for bone and cartilage study. Cybium, 9: 107-119

Whitehead, P.J.P. (1985). FAO species catalog. Clupeoid fishes of the world (suborder Clupeoidei). Part 1 Chirocentridae, Clupeidae and Pristigasteridae. FAO Fisheries Synopsis, 7: 1-304.

Whitehead, P.J.P., G.J. Nelson \& T. Wongratana (1988). Clupeoid fishes of the world (Suborder Clupeoidei). An annotated and illustrated catalogue of the herrings, sardines, pilchards, sprats, anchovies and wolf-herrings. Part 2. Engraulididae. FAO species catalogue. Fisheries Synopsis, (125), 7. Roma: FAO. 